\title{
Partnerships in mathematics and science teacher preparation in Zimbabwe
}

\author{
Alois Matorevhu \\ Mutare Teachers' College, P. O. Box 3293, Paulington, Mutare, Zimbabwe

\begin{tabular}{ll}
\hline A R T I C L E I N F O & A B S T R A C T \\
Original Article & Research evidence indicates that collaborative partnerships among \\
doi:10.18860/ijtlm.v2i2.9341 & stakeholders develop strong sense of ownership, interest and \\
\hline Keywords: & commitment, which promotes successful programme \\
Collaborative Partnership, & implementation. Research evidence also supports that loose \\
Stakeholders, Programme & partnerships adversely affect programme implementation. This \\
Implementation & study sought to explore the nature of partnerships among teacher \\
& education stakeholders in the pre-service Diploma in Education \\
& programme, offered at Teachers' College S which is an associate of \\
& the University of Zimbabwe. Interviews with mentor teachers, pre- \\
& service teachers on attachment teaching practice/practicum, and \\
& head teachers were used to generate and collect data. Findings \\
& revealed existence of collaborative partnerships among Teachers' \\
College S, schools and the University of Zimbabwe. However, \\
most mentor teachers expressed concern on absence of a policy \\
guiding their operations. Recommendations to strengthen \\
collaborative partnerships in pre-service teacher preparation were \\
made.
\end{tabular}

(C) 2019 IJTLM. All rights reserved.

*Alois Matorevhu

E-mail: amatorevhu@gmail.com

How to cite: Matorevhu, A. (2019). Partnerships in mathematics and science teacher preparation in Zimbabwe. International Journal on Teaching and Learning Mathematics, 2(2), 39-51.

\section{INTRODUCTION}

Economy and society are held together and advanced by building relationships and knowledge sharing. Collaboration is an important component of any partnership which can drive issues of national interest like education for sustainable development in the $21^{\text {st }}$ century, based on a common vision and sharing of ideas by stakeholders (Martin, Tett, \& Kay, 1999). Collaboration entails working together of two or more individuals or groups with different interests to achieve a common goal by pooling knowledge, skills and resources (OECD, 2013). When a partnership is collaborative, consenting organisations share resources (such as finances, knowledge, material and human) to accomplish a mutual goal, for mutual benefit. To ensure that education for sustainable development prevails, collaborative partnerships should be self-organising and coordinating, with actors from two or more spheres of society working for sustainability (Karatzoglou, 2013).

In classroom practice, collaborative teaching implies coactive and coordinated teaching by various teachers to improve performance of individual teachers through observation of teaching by colleagues, and subsequent discussion of the teaching and learning process of lessons collaboratively taught (Boudah, Schumacher, \& Deshler, 1997). Although, in teacher education capitalizing on each other's knowledge and expertise through collaborative partnership helps 
pre-service teachers in developing professional competence, college and university teacher education is criticized for failing to equip pre-service teachers with extensive training and experience in collaborative teamwork (Cortez, Nussbaum, Woywood, \& Aravena, 2009). Preservice teacher preparation is no longer a total responsibility of teacher education institutions, but a collaborative partnership among various stakeholders. Taylor, Cook, Green, \& Keith Rogers (1988) identify a trustworthy working climate, and sense of ownership of activities as some of the benefits of collaborative partnership which improve achievement. Collaborative partnership builds on strength, talents, resources and expertise of educators and the community in general.

Although most teaching practices support school - university collaborative partnerships, many of these partnerships demonstrate problems related to organizing and monitoring teaching practice (Kecik \& Aydin, 2011). Most collaborative partnerships have been criticised for failing to establish an equal relationship between school teachers (practitioners) and the university or college supervisors (academics) These loose partnerships adversely affect teacher education programme implementation. Valencia, Martin, Place, \& Grossman (2009) identify disorganisation as a problem in teacher education, due to lack of preparation and support needed in guiding pre-service teachers. Zeichner (2010) argues that an equal and more dialectical relationship between the academic and the practitioner is necessary for building bridges between universities and schools. Only such a relationship can enable school teachers (mentor teachers) to help pre-service teachers in linking theory learnt at university or college with practice.

Teacher education must change to prepare pre-service teachers with knowledge, skills, attitudes and ability to facilitate teaching and learning collaboratively, as expected of $21^{\text {st }}$ century teachers (Arthaud, Aram, Breck, Doelling, \& Bushrow, 2007). Teacher educators should examine the collaborative process aiming to clarify exit competences expected of preservice teachers. To develop such competences in pre-service teachers, teacher educators must adjust programmes to the implications of these changes, to effectively prepare teacher candidates for this new milieu (Bruïne et al., 2018).

Teacher preparation programmes seek to assist pre-service teachers to transform experiences into personal knowledge structures in flexible ways which include collaborative teaching (Bouldin, 2017). For instance, trailing new approaches in preparing pre-service teachers for diverse, inclusive classrooms has facilitated teacher educators to work closely with schools. These collaborative partnerships foster conducive experiences and competences of inclusive teachers to cater for students with disabilities (Florian, 2012). Among models that can be used in science teacher education collaborative partnership between practising and pre-service teachers, is the mentor type (Jones, 2008), which enhances collaborative planning, implementation and reflection on a series of science lessons in cycles. The mentor collaborative partnership model is premised on that professional learning occurs to both the practising and pre-service teachers, since both the expert (mentor teacher) and novice partner (pre-service teacher) contribute to the teaching and learning process (Jones, 2008). Therefore mutual respect should prevail among stakeholders in a collaborative partnership.

Pres - service teachers' deeper understanding about themselves and others, as revealed by several studies (Bentley-Williams \& Morgan, 2013), is enhanced by reflexive learning which entails embracing subjective understandings of reality as a basis for thinking more critically about the impact of one's assumptions, values, and actions on others (Reich, 2017). It then implies for sustainability stakeholders must nurture conditions conducive for collaborative partnership.

In previous studies mentor teachers have shown disgruntlement with their roles in teacher 
education, and that the gulf between university and schools was great (Graham \& Hudson-Ross, 1999). Approaches such as participation in professional learning of school sectors and universities, have been identified by previous inclusive education studies to give support needed in early formative career development (Florian, 2012). It is therefore prudent to use effective ways of implementing these approaches in collaborative partnerships, to develop intended competences in pre-service teachers, for subsequent improvement of teaching and learning in schools. While collaborative partnership assumes equal participation by stakeholders, previous research (Graham \& Hudson-Ross, 1999), shows that mentor teachers felt less knowledgeable than university supervisors, a view university supervisors held, so mentor teachers neither volunteered to contribute nor were given the chance to. In this context mentor teachers were not sure whether they provided university teacher educators the model of pre-service teachers they envisioned. Therefore instead of contributing, compliance and silence were preferred comfortable options by mentor teachers, than risking being judged wrong (Graham \& HudsonRoss, 1999).

Most influential experience reported by graduates of teacher preparation programmes was the practicum (Zeichner, 2010), but teacher education programmes encountered challenges in effectively bridging theory and practice during the practicum. Haphazard practicums provided by some universities with pre-service teachers getting little or no support (Hoffman \& Adams, 2018), resulted in lack of opportunities for pre-service teachers to gain new experiences as well as reflecting on their teaching philosophies (Maynard, La Paro, \& Johnson, 2014). Attachment Teaching Practice (ATP) sites characterised by diversity and innovation are what universities should offer to better support pre-service teacher preparation (Nyabadza \& Mutendera, 2014). This allows teacher education programmes to depart from traditional approaches, thereby developing new models of preparing teachers consistent with $21^{\text {st }}$ century teaching and learning (Zeichner, 2010). Exposing pre-service teachers to a variety of opportunities in different learning environments where they observe, and reflect on their practice in nontraditional setting (Lim \& Chan, 2007), assists them to process and connect new experiences into their philosophical approaches and beliefs about (Maynard et al., 2014). Pre-service teachers view family - school collaboration with optimism, that stronger family - school bond imply greater learner educational benefit (Ozturk, 2017). Educational environments like community programmes, allow pre-service teachers to gain real - world experiences that cannot occur in formal classroom settings. These authentic field experiences enable prospective teachers to develop competences to facilitate learning in diverse contexts (California State University (CSU), 2018; Wasburn-Moses, Kopp, \& Hettersimer, 2012). In this sense implementation entails context sensitive or adaptive instruction, which pre-service teacher institutions should embrace.

The establishment of collaborative partnerships is not a spontaneous process without structures, but is purposefully initiated and well organized (Smith, Gartin, \& Murdick, 2011). Fundamentally partners act from a clearly expressed intent toward a common goal, striving for mutual success, but with investments and activities advancing their institutional aims (CSU, 2018). In collaborative partnership the role for each stakeholder needs to be explicit, particularly in the light of in - service teachers who may not readily access information provided by universities. Partnerships are beneficial if teachers are afforded the chance to reflect on their practice and collaboratively work with pre-service science teachers (Barnett, 2006; Herold, F., \& Waring, M. (2018; MaKinster, Barab, Harwood, \& Andersen, 2006).

Family-school partnership is an important aspect which can contribute to provision of 
relevant learning experiences to learners, yet it is neglected (Willemse, Thompson, Vanderlinde, $\&$ Mutton, 2018). While benefits of collaborative partnerships are acknowledged, Petersen \& Treagust (2014) remind that challenges that can be encountered in developing partnerships between tertiary institutions and schools, like schools being viewed as junior partners by universities, may derail effective implementation of collaborative partnerships (Ryan, Young, \& Kraglund-Gauthier, 2017). This calls for the need of universities to create a collaborative environment in which all stakeholders feel equal, and important players in the partnership. It is important to note that effective collaboration is not an event, but a sustained process of development and implementation for which teachers facing challenges from daily tasks, limited resources, and pressure to demonstrate instructional competency may not find time needed (Burton, 2015) . Models among which teacher education intuitions can choose are many, but regardless of model adapted, a comprehensive collaborative plan, that aligns the university, culture of the school, needs of teachers and learners is needed (Burton, 2015).

Many pre-service teachers have been observed to experience isolation during field placement/ATP (Valencia et al., 2009), apparently with no corresponding support by universities (Barmore, 2016). Supported pre-service teachers during ATP have been observed to effectively implement and retain learnt skills with careful goal setting, collaboration among participants, and teacher educator guidance as important success drivers (Kervinen et al., 2016). Requisite skills needed to implement co - teaching practices, such as developing a collaborative relationship with an individual from a different professional background and being able to effectively resolve conflict have been found missing from general conceptions of co - teaching (Weiss, Pellegrino, \& Brigham, 2017). These are issues pre-service teacher programmes should focus on for collaborative partnerships to succeed.

\section{Pre-service Diploma in Education Programme in Zimbabwe}

The University of Zimbabwe (UZ) offers Diplomas in Secondary and Primary Education for those who train as secondary and primary school teachers respectively (Department of Teachers Education/DTE). Training is offered in secondary and primary teachers colleges which are UZ associate colleges in Diploma in Education training programme. Pre-service teachers work during ATP under the guidance of mentor teachers, hence it is called Attachment Teaching Practice (ATP). DTE teacher educators, College teacher educators (lecturers) and mentor teachers assess pre-service teachers during ATP and award grades which contribute to the final grade for ATP assessment.

The University of Zimbabwe Scheme of Association identifies the University of Zimbabwe (UZ), Ministry of Higher and Tertiary Education, Science and Technology Development (MHTESTD), Ministry of Primary and Secondary Education (MoPSE) and Associate Primary and Secondary Teachers Colleges in Zimbabwe as stakeholders. This study sought to explore the nature of partnerships among stakeholders and the effects of these partnerships on Diploma in Education programme for pre-service secondary teachers (Mathematics and Science), offered at associate Teachers' College $\mathrm{S}$.

\section{METHOD}

A case study design consisting mixed methods approach involving a questionnaire survey, interviews and document analysis was used. Through triangulation, interviews and document analysis validated questionnaire data as well as increasing quality and scope of findings.

Twenty five secondary schools participated in the study. A questionnaire was purposefully 
administered to the head teacher and four mentor teachers at each secondary school. Head teachers and mentor teachers were purposively sampled, because they were directly involved in the Diploma in Education programme activities through administration and mentoring respectively. The researcher and colleagues distributed copies of the questionnaire for feeling in and collected them soon after being completed during supervision visits to pre-service teachers on ATP. Although the questionnaire comprised strongly agree, agree, undecided, disagree and strongly disagree as optional responses, for easy analysis these where collapsed into three categories namely agree, undecided and disagree. Interviews were done with some head teachers, mentor teachers, teacher educators and pre-service teachers at Teachers' College S. Documents that were analyzed are the Handbook for Quality Assurance in Associate Teachers' Colleges of 2015 which contains the UZ Scheme of Association with Teachers' Colleges in Zimbabwe, Teachers' College S Attachment Teaching Practice (ATP) handbook, Teachers' College S Graduation Booklets (2009 - 2013), workshop reports. Data from questionnaires were analysed quantitatively while, data from interviews and documents were qualitatively analysed. Information from analysis of data from various sources validated findings through triangulation.

\section{RESULTS AND DISCUSSION}

As shown in Table 1 respondents rated cooperation of schools with Teachers' College $\mathrm{S}$ on design of pre-service teacher course requirements at $64 \%$, collaboration with Teachers' College $\mathrm{S}$ on placement (deployment) of pre-service teachers in schools for ATP at $84 \%$, involvement of schools (mentor teachers and head teachers) adequately in pre-service teacher assessment on ATP at $92 \%$, and consideration of views of schools on selection of prospective pre-service teachers at $68 \%$.

Table 1. Summary of responses on the questionnaire survey

\begin{tabular}{|c|c|c|c|c|c|c|}
\hline Statement & Agree & $\%$ & Undecided & $\%$ & Disagree & $\%$ \\
\hline $\begin{array}{l}\text { 1. Our school collaborates with the College on } \\
\text { the design of pre-service teacher course } \\
\text { requirements }\end{array}$ & 80 & 64 & 10 & 8 & 35 & 28 \\
\hline $\begin{array}{l}\text { 2. Our school collaborates with the College in } \\
\text { placement (deployment) of student teachers into } \\
\text { schools. }\end{array}$ & 105 & 84 & 5 & 4 & 15 & 12 \\
\hline $\begin{array}{l}\text { 3. The school (mentors, administrators) are } \\
\text { adequately involved in student teachers' } \\
\text { assessment on ATP. }\end{array}$ & 115 & 92 & 0 & 0 & 10 & 8 \\
\hline $\begin{array}{l}\text { 4. The College considers our mentor teachers' } \\
\text { views in the selection of prospective pre-service } \\
\text { teachers during selection. }\end{array}$ & 85 & 68 & 20 & 16 & 20 & 16 \\
\hline $\begin{array}{l}\text { 5. The idea that the external examiners' (from } \\
\text { the University of Zimbabwe) mark overrides all } \\
\text { other assessments is good. }\end{array}$ & 30 & 24 & 15 & 12 & 80 & 64 \\
\hline $\begin{array}{l}\text { 6. The idea that teacher educators (lecturers) } \\
\text { supervise students and leave without giving } \\
\text { feedback to the mentor is disempowering. }\end{array}$ & 115 & 92 & 0 & 0 & 10 & 8 \\
\hline $\begin{array}{l}\text { 7. If pre-service teachers are not involved on } \\
\text { issues related to their work during ATP they } \\
\text { become less effective }\end{array}$ & 125 & 100 & 0 & 0 & 0 & 0 \\
\hline $\begin{array}{c}\text { 8. The College should always take lead } \\
\text { decisions on matters to do with pre-service } \\
\text { teachers on ATP. }\end{array}$ & 105 & 84 & 5 & 4 & 15 & 12 \\
\hline
\end{tabular}




\begin{tabular}{|c|c|c|c|c|c|c|}
\hline $\begin{array}{l}\text { 9. The Ministry of Primary and Secondary } \\
\text { Education (MoPSE) has a comprehensive policy } \\
\text { guideline on how mentors operate. }\end{array}$ & 30 & 24 & 15 & 12 & 80 & 64 \\
\hline $\begin{array}{l}\text { 10. At school level during ATP, pre-service } \\
\text { teachers are allocated teaching resources. }\end{array}$ & 90 & 72 & 30 & 24 & 5 & 4 \\
\hline $\begin{array}{l}\text { 11. The school at which I teach has all College } \\
\text { documents that communicate expected } \\
\text { outcomes during ATP. expectations . }\end{array}$ & 70 & 56 & 5 & 4 & 50 & 40 \\
\hline $\begin{array}{l}\text { 12. The College communicates ATP } \\
\text { expectations through workshops. }\end{array}$ & 70 & 56 & 5 & 4 & 50 & 40 \\
\hline
\end{tabular}

Although some areas were rated higher than others, but a minimum of $64 \%$ shows that relatively a strong collaborative partnership exists between Teachers' College $\mathrm{S}$ and secondary schools in the pre-service Diploma in Education programme. However, overriding of assessments by Teachers' College S and mentor teachers by the UZ external examiners' assessment marks was rated bad at $64 \%$. This may be interpreted to imply nullification of the whole assessments by Teachers' College $\mathrm{S}$ and mentor teachers (schools). While it is encouraging that they are many areas in which head teachers and mentor teachers rated positively, areas of concern shown by negative rating need to be attended to. This would produce the best teachers who engender education for sustainable development (ESD), since such teachers would facilitate learning for the world of work and life in general. Need for Empowerment, Guiding Information, Support for Pre-service Teachers, and School and Community Interaction are themes which emerged in this study, and are articulated in the following description.

\subsection{Need for Empowerment}

Feedback empowers stakeholders to formatively fine tune implementation with focus on achieving programme objectives. However, in the current study mentor teachers viewed lack of feedback from teacher educators as disempowering which reduced effectiveness of pre-service teachers suggesting that pre -service teachers may not develop the skills necessary for the teaching profession, yet development of such skills is a key objective of ATP. This was supported by a mathematics mentor teacher Y saying:

Sometimes college supervisors leave after supervising pre-service teachers without giving feedback to the mentor teacher or head teacher. As for the University supervisors, they do not give any feedback at all. Schools are left in dark as to which areas need attention in terms of improvement, so that the quality of preservice teacher preparation is improved.

This sentiment is echoed by (Graham \& Hudson-Ross, 1999), saying de facto exclusion of mentor teachers by university supervisors in ATP implementation is an indicator that supervisors neither value nor understand the role of teachers in pre-service teacher preparation. As collaborative partnership espouses, equal participation by stakeholders should be pivotal in Teachers' College S - schools partnership as well as UZ - schools partnership. Such mutual recognition and respect by stakeholders in these and similar partnerships, is bound to strengthen the sense of ownership of the programme which improves quality of pre-service teacher graduates, with the ultimate improvement of quality of school graduates, due to high quality teacher performance. This was reiterated by head teacher $\mathrm{N}$ who stressed the need of feedback from the university and Teachers' College $\mathrm{S}$ as formative assessment which helps programme implementation improvement commenting that: 
Feedback given by the UZ and Teachers' College $S$ is formative assessment, which helps us to reflect on our practice as schools, mentor teachers and head teachers, so that we make necessary adjustments to improve the quality of experience preservice teachers get develop during attachment teaching practice (ATP). However if feedback is not given it demoralises us from committing ourselves in supporting pre-service teacher preparation.

Also stressing the need to share outcomes of supervision by college teacher educators, a science mentor teacher F said:

College supervisors should give feedback on their observations, so that the school and the college can share ideas on how to establish a good working relationshipThe feedback allows schools to focus ATP activities in line with what the College expects. Sharing information with college supervisors make us feel honoured and relevant, hence motivated to be committed to genuinely implement.

The views expressed by head teacher $\mathrm{N}$ and science mentor teacher $\mathrm{F}$ are corroborated by CSU (2018) that while partners have the obligations to advance their institutional aims, but with regards collaborative partnership, partners should act form a clearly expressed intent toward the same goal. Concurring with head teacher $\mathrm{N}$ and mentor teacher $\mathrm{F}$, science teacher educator $\mathrm{K}$ acknowledged the need to give feedback to school partners, but raised some concerns:

It is very important that the school administration through its representative is given feedback on strengths and weaknesses, and share ideas on how to improve. However, time in the context of a large number of pre-service teachers needing supervision, is a very strong limitation.

Also corroborating teacher educator K's view mathematics teacher educator P said:

Both mentor teachers and pre-service teachers need feedback and sharing of views with college supervisors, so that all effort put into teacher preparation focus on producing the best teacher for the best school graduate.

Basically, the study reveals resonance in thinking among schools and Teachers' Collage S, about the collaborative partnership which should exist in pre-service teacher preparation. However, there is need to ensure that conditions like time and workload are promoters rather than inhibitors, of achievement of goals in pre-service teacher preparation.

\subsection{Guiding Information}

Success of collaborative partnership should be premised on roles of respective stakeholders being explicit. Concurring head teacher $\mathrm{P}$ articulated that:

The Ministry of Primary and Secondary Education (MoPSE) should have clear policy guidelines showing how head teachers and mentor teachers should contribute to pre-service teacher training. Most of the teachers who graduate from the teacher education institutions in Zimbabwe will work in MoPSE, so it is wise that the Ministry assists in producing the teacher it wants.

The grand question to be asked is, "Is the programme producing the desired teacher by MoPSE?" Some answers to this question are evident from mathematics mentor teacher G who commented on the effectiveness of the collaborative partnership between Teachers' College $\mathrm{S}$ and schools that:

More information sharing is needed so that both schools and the college are made aware where the teacher preparation programme is doing well and where 
improvement is needed. This assists in focusing on equipping pre-service teachers with desired exit competences.

Responses by mentor teacher $\mathrm{G}$ and head teacher $\mathrm{P}$ show appreciation of the good quality of pre-service teachers being prepared, but expressing the need to improve by working together collectively, through a collaborative partnership, with clear policy guidelines. Through questionnaire responses head teachers and mentor teachers expressed the need for comprehensive policy on how they should operate in MoPSE, by a rating of 64\%. Absence of such a policy suggests that they are no stipulated conditions of service (that is, allowances, workload and recognition) for teacher mentors. This may weaken the collaborative partnership between Teachers' College S and schools.

\subsection{Support for Pre-service Teachers}

Lack of Teachers' College S ATP documents in schools affected the level of understanding the expected roles head teachers and mentor teachers should play, giving them an impression of a junior partner in the teacher preparation process. This concern by head teachers and mentor teachers is illustrated by science mentor teacher $\mathrm{V}$ commenting that:

For the greater part of ATP schools are responsible for day to day support of preservice teachers, except for short periods when they go to college for workshops, and when Teachers' College S and University educators come to supervise them.

Premised on these sentiments, both Teachers' Colleges S and the UZ should recognise and treat schools as important collaborative partners. During interviews corroborating head teachers $\mathrm{T}$ and W's views, mathematics mentor teacher Q commented:

Frequent workshops should be held with mentors, and schools heads, to share ideas on how to best support pre-service teachers during ATP, consistent with expectations of the college. Documents from the college should be discussed during such workshops so that stakeholders in schools have clear understanding of how they should help the pre-service teachers on ATP.

These results show the need to improve the availability of Teachers' College S ATP linked documents to schools as well as holding more workshops with schools on ATP, hence increasing the strength of partnership. In particular head teachers $\mathrm{T}$ and $\mathrm{W}$ and mentor teacher D's responses point out to the need for a close collaborative partnership between schools and teacher preparation institutions, to ensure pre-service teachers are supported to develop desired competences to facilitate effective instruction for education for sustainable development (ESD).

Asked how pre-service teachers viewed the working relationship between them and teacher mentors was, pre-service teachers variedly responded. Their responses reflected a range from a good working relationship to a stressful loaded teaching and learning environment. For instance Pre-service mathematics teacher U commented:

My mentor is very understanding and concerned about my success in the programme. Teaching and learning aids are made available without problems. I am given affordable teaching load and other duties which strikes a balance between learning direct course requirements and developing other necessary skills like managing situations, making decisions independently and socialising.

Also pre-service science teacher $\mathrm{M}$, at variance with $\mathrm{U}$, commented distressfully that:

There are worrying challenges in my ATP. My mentor gives me most of the work to do as if I am qualified. It is like all the load and other duties of the mentor teacher 
have been off loaded on me, so I am experiencing so much pressure. I need help to make me feel comfortable by reducing my load to reasonable levels.

Truly pre-service teachers $U$ and M's responses are samples which corroborate varied responses which were given by other pre-service teachers who were interviewed. The responses reflect a dichotomy whereby some pre - services teachers' ATP experiences were good supportive working relationship (collaborative partnership) with mentor teachers, but for others experiences were pressurising due to unsupportive mentor teachers. Consolidating good work of supportive mentor teachers, and guiding unsupportive mentor teachers can be achieved by developing a ATP implementation framework. This will help mentor teachers, heads of departments and head teachers doing well to consolidate their strengths, and those not doing as expected to align their roles in pre-service teacher preparation with Teachers College S's expectations. Such an approach will improve the production of the envisaged pre-service teachers who will be good beginners upon joining the teaching profession.

\subsection{School and Community Interaction}

Focus of schools should be on ensuring that school operations are embedded into the community, so that knowledge, skills and values learners develop are not divorced from real life. This suggests that pre-service teacher preparation should initiate prospective teachers on how to collaborate with the community to engender skills to facilitate education for sustainable development. Asked whether the school and the community partnership had a play bearing on pre-service teacher preparation, mentor teachers unanimously agreed, but were quick to point out that in practice it was conspicuous by its absence in pre-service teacher preparation. This is illustrated by mathematics mentor teacher $\mathbf{J}$ saying:

Pre-service teachers need to develop skills to work with the local community and contribute to its development, but the college curriculum does not include this Schools do not initiate pre-service teachers into such activities since they mentor pre-service teachers as guided by the college.

Teachers' College $\mathrm{S}$ in this context need to include community related activities in the curriculum for pre-service teachers while on ATP, so that they develop skills to link theory they do at college with real life community experiences.

\subsection{Document Analysis}

Documents that were analyzed are the Handbook for Quality Assurance in Associate Teachers' Colleges of 2015 which contains the University of Zimbabwe (UZ) Scheme of Association with Teachers' Colleges in Zimbabwe, Teachers' College S Attachment Teaching Practice (ATP) Handbook, Teachers' College S Graduation Booklets (2009 - 2019), and workshop reports.

\subsection{Handbook for Quality Assurance in Associate Teachers' Colleges}

In this handbook the Scheme of Association is defined as a collective responsibility among several stakeholders which are the UZ, the Ministry of Higher and Tertiary Education, Science and Technology Development (MHTESTD), Ministry of Primary and Secondary Education (MoPSE) and Associate Primary and Secondary Teachers' Colleges. The nature of operation of the Scheme of Association is reflected by the roles of each stakeholder. The general principles of operation of the Scheme of Association are collective responsibility, dialogical management and consultation. The implementing agency is the UZ through the Department of Teacher Education (DTE). 
According to UZ DTE 2015's Scheme of Association stakeholders are: DTE (UZ), Teachers' College $S$ and MoPSE which provides both secondary schools for pre-service teachers to do ATP and mentor teachers. However, interviews with head teachers and mentor teachers (schools) revealed a of lot concern on lack of direct involvement of schools in some DTE Diploma in Education programme activities, like implementation of effective pre-service teacher preparation strategies, yet schools spent most of the ATP period assisting pre-service teachers to develop skills relevant to the teaching profession. Teachers' College $\mathrm{S}$ educators as internal supervisors and UZ teacher educators as external supervisors spent at most no more than an hour with a pre-service teacher during ATP supervision. Spending short time by both internal and external supervisors was attributed to lack of time due to the large number of preservice teachers needing supervision. Although it can be argued that MoPSE represents schools, but the head teachers and mentor teachers were concerned that MoPSE did not recognize the Diploma in Education related activities which they did as part of their official duties. Mentor teachers said they were affected most since being a mentor implicitly implied more workload, since mentoring increased mentor teachers' workload. Indirect involvement of schools in DTE Diploma in Education activities and lack of recognition of the role of schools in ATP tended to weaken schools - Teachers' College S and schools - DTE (UZ) collaborative partnerships.

\subsection{Other Documents}

Analysis of other documents revealed some partnerships whose stakeholders are not stated in the UZ Scheme of Association, yet such partnerships play important roles in the Diploma in Education programme implementation. For instance, Teachers' College S Graduation booklets (2009 - 2019) showed that the local business community supported financially and materially important events like Teachers' College S graduation ceremonies. Workshop reports showed that NGOS like Vlaamse Vereniging voor Ontwikkelings samenwerking en Techinsche Bijstand (Flemish Association for Development Cooperation and Technical Assistance) (VVOB) supported workshops, for instance the workshop held at Teachers' College S on mentorship in 2014. The report on this workshop describes expectations of pre-service teachers, mentor teachers, teacher educators and schools. Also described in the report are mentor teachers and head teachers' expectations of Teachers' College $\mathrm{S}$ teacher educators and pre-service teachers. Lastly, the expectations of Teachers' College $\mathrm{S}$ of schools are described. Expressing how preparing prospective teachers consistent with expectations of stakeholders motivates them to readily participate in ways which achieve programme goals head teacher $\mathrm{L}$ who commented that:

If expectations of all stakeholders are given due consideration, effort put in programme implementation will be directed towards equipping pre-service teachers with appropriate competences for the teaching profession.

Analysis of Teachers' College S ATP Handbook for pre-service teachers and mentor teachers showed that information on issues regarding requirements for successful implementation of ATP was clearly explained in the booklet. The purpose of this was to develop a common vision and understanding of what ATP is, and how it should be implemented, hence strengthening the collaborative partnership between pre-service teachers and their mentor teachers. However, mentor teachers, head of departments in schools and head teachers indicated during interviews that the ATP booklet as a source of information was not readily available to them. Therefore there is need to disseminate such information in order to strengthen collaborative partnerships among schools, pre-service teachers and Teachers' College $\mathrm{S}$. 


\section{CONCLUSION}

In this study collaborative partnership seems to be a working relationship which is either written or not, among stakeholders who sought to further interests / objectives of a group or organization. However, it would be most preferable for the collaborative partnership to have a written guiding operational framework, so that if ever anybody wants clarity, reference will be easily made with the document. It is concluded that in practice they are more stakeholders than the UZ Scheme of Association recognizes, which are in collaborative partnerships in the preservice Diploma in Education programme. While UZ recognises DTE of the UZ, Teachers' College $\mathrm{S}$ and MoPSE which provides both secondary schools for pre-service teachers to do ATP and mentor teachers as collaborative partners, NGOs, the business community and industry need to be recognised by regularising their involvement in collaborative partnership of preparing pre-service teachers. In particular, the business community and teacher education institutions collaborative partnerships form public - private partnerships (PPPs), which are viewed worldwide as means of promoting socio - economic development (World Tourism Grganization, 2015; Irfan, Salman, Jabeen, Ahmad, \& Ansari, 2017). On behalf of the UZ, Teachers' College S should be directly involved in the PPPs. In view of respondents' concerns, and in the spirit of inclusivity, the University of Zimbabwe (UZ) should broaden description of stakeholders taking cognizant of the different roles stakeholders play in the partnership. As the programme owner, the UZ should develop a policy which creates symbiotic working relationships among MoPSE, Teachers' College S, the UZ, NGOs, business community and industry as stakeholders in partnerships.

\section{REFERENCES}

Arthaud, T. J., Aram, R. J., Breck, S. E., Doelling, J. E., \& Bushrow, K. M. (2007). Developing collaboration skills in pre-service teachers: A partnership between general and special education. Teacher Education and Special Education, 30(1), 1-12.

Barmore, J. (2016). Pre-Service Teacher education: Connecting teaching principles to teaching practice (Doctoral dissertation). Harvard Graduate School of Education.

Barnett, M. (2006). Using a web-based professional development system to support preservice teachers in examining authentic classroom practice. Journal of Technology and Teacher Education, 14(4), 701-729.

Bentley-Williams, R., \& Morgan, J. (2013). Inclusive education: Pre-service teachers' reflexive learning on diversity and their challenging role. Asia-Pacific Journal of Teacher Education, 41(2), 173-185.

Boudah, D. J., Schumacher, J. B., \& Deshler, D. D. (1997). Collaborative instruction: Is it an effective option for inclusion in secondary classrooms? Learning Disability Quarterly, 20(4), 293-316.

Bouldin, A. S. (2017). Reflection is not reflexive. American Journal of Pharmaceutical Education, 81(9), 6832.

Bruïne, E. D., Willemse, T. M., Franssens, J., Eynde, S. V., Vloeberghs, L., \& Vandermarliere, L. (2018). Small-scale curriculum changes for improving pre-service teachers' preparation for Family-School Partnerships. Journal of Education for Teaching, 44(3), 381-396.

Burton, T. (2015). Exploring the impact of teacher collaboration on teacher learning and development (Doctoral dissertation). University of South Carolina. 
Cortez, C., Nussbaum, M., Woywood, G., \& Aravena, R. (2009). Learning to collaborate by collaborating: A face-to-face collaborative activity for measuring and learning basics about teamwork 1. Journal of Computer Assisted Learning, 25(2), 126-142.

CSU. (2018). The power of partnership in teacher preparation: Preparing a new generation of educators for California. Brief $1,1-9$.

Florian, L. (2012). Preparing teachers to work in inclusive classrooms: Key lessons for the professional development of teacher educators from Scotland's inclusive practice project. Journal of Teacher Education, 63(4), 275-285.

Graham, P., \& Hudson-Ross, S. (1999). Teacher candidate research on literacy in high school classrooms. Teacher/Mentor: A Dialogue for Collaborative Learning, 65-79.

Herold, F., \& Waring, M. (2018). An investigation of pre-service teachers' learning in physical education teacher education: Schools and university in partnership. Sport, Education and Society, 23(1), 95-107.

Hoffman, K. T. \& Adams, M. (2018). Re-envisioning student teaching and field experiences: Partnerships with community. Texas Child Care Quarterly, 42(1), 1-5.

Irfan, S., Salman, Y., Jabeen, N., Ahmad, S. I., \& Ansari, N. G. (2017). Towards understanding relational aspects of inter-organizational collaboration: An exploration of public-private partnerships in pakistan. Pakistan Economic and Social Review, 55(1), 53-79.

Jones, M. M. (2008). Collaborative partnerships: A model for science teacher education and professional development. Australian Journal of Teacher Education, 33(3), 61-76.

Karatzoglou, B. (2013). An in-depth literature review of the evolving roles and contributions of universities to education for sustainable development. Journal of Cleaner Production, 49, 44-53.

Kecik, I., \& Aydin, B. (2011). Achieving the impossible?: Teaching practice component of a pre-service distance English language teacher training program in Turkey. Australian Journal of Teacher Education (Online), 36(4), 73.

Kervinen, A., Uitto, A., Kaasinen, A., Portaankorva-Koivisto, P., Juuti, K., \& Kesler, M. (2016). Developing a collaborative model in teacher education-An overview of a teacher professional development project. LUMAT: International Journal on Math, Science and Technology Education, 4(2), 67-86.

Lim, C. P., \& Chan, B. C. (2007). MicroLESSONS in teacher education: Examining pre-service teachers' pedagogical beliefs. Computers \& Education, 48(3), 474-494.

MaKinster, J., Barab, S., Harwood, W., \& Andersen, H. (2006). The effect of social context on the reflective practice of preservice science teachers: Incorporating a web-supported community of teachers. Journal of technology and teacher education, 14(3), 543-579.

Martin, J., Tett, L., \& Kay, H. (1999). Developing collaborative partnerships: Limits and possibilities for schools, parents and community education. International Studies in Sociology of Education, 9(1), 59-75.

Maynard, C., La Paro, K. M., \& Johnson, A. V. (2014). Before student teaching: How undergraduate students in early childhood teacher preparation programs describe their early classroom-based experience. Journal of Early Childhood Teacher Education, 35(3), 244-261.

Nyabadza, G., \& Mutendera, G. (2014). Stress management among female student teachers on attachment teaching practice: The case of Marymount Teachers College, Zimbabwe. International Journal of Social Science and Education, 4(2), 429-436. 
OECD. (2013). PISA 2015: Draft collaborative problem solving framework. OECD Publishing.

Ozturk, M. E. (2017). Collaboration with Families: Perceptions of Special Education Preservice Teachers and Teacher Preparation (Doctoral dissertation). University of South Florida.

Petersen, J. E., \& Treagust, D. F. (2014). School and university partnerships: The role of teacher education institutions and primary schools in the development of preservice teachers' science teaching efficacy. Australian Journal of Teacher Education, 39(9), 153-167.

Reich, Y. (2017). The principle of reflexive practice. Design Science, 3, 1-27. https://doi.org/10.1017/dsj.2017.3

Ryan, T. G., Young, D. C., \& Kraglund-Gauthier, W. L. (2017). Action research within preservice teacher education. Transformative Dialogues: Teaching \& Learning Journal, 10(3), 1-18.

Smith, T. E., Gartin, B. L., \& Murdick, N. L. (2011). Including adolescents with disabilities in general education classrooms. Pearson Higher Ed.

Taylor, L. K., Cook, P. F., Green, E. E., \& Keith Rogers, J. (1988). Better interviews: The effects of supervisor training on listening and collaborative skills. The Journal of Educational Research, 82(2), 89-95.

Valencia, S. W., Martin, S. D., Place, N. A., \& Grossman, P. (2009). Complex interactions in student teaching: Lost opportunities for learning. Journal of Teacher Education, 60(3), 304-322.

Wasburn-Moses, L., Kopp, T., \& Hettersimer, J. E. (2012). Prospective teachers' perceptions of the value of an early field experience in a laboratory setting. Issues in Teacher Education, 21(2), 7-22.

Weiss, M. P., Pellegrino, A., \& Brigham, F. J. (2017). Practicing collaboration in teacher preparation: Effects of learning by doing together. Teacher Education and Special Education, 40(1), 65-76.

Willemse, T. M., Thompson, I., Vanderlinde, R., \& Mutton, T. (2018). Family-school partnerships: A challenge for teacher education. Taylor \& Francis.

Zeichner, K. (2010). Rethinking the connections between campus courses and field experiences in college-and university-based teacher education. Journal of Teacher Education, 61(12), 89-99. 